\title{
Art and culture as a viable currency in Yoruba traditional architecture
}

\author{
P. S. O. Aremu ${ }^{1}$, O. J. Ajiboye ${ }^{1} \&$ B. Abiodun ${ }^{2}$ \\ ${ }^{I}$ Department of Fine and Applied Arts, Obafemi Awolowo University, \\ IIe- Ife, Nigeria \\ ${ }^{2}$ Department of Creative Arts, \\ Tai-Solarin University of Education Ijebu Ode, Nigeria
}

\begin{abstract}
The definition of art and culture is wholly embedded in the traditional architecture of the Yoruba people of the south-western part of Nigeria. This paper therefore highlights the relevance of culture and the artistic norms of the Yoruba regarding their much cherished traditional architecture with special reference to the artistic elements (figures, symbols, patterns etc,) as used to meet the aesthetic and creative ingenuity of their architecture. African traditional architecture encompasses interpretation and adaptation of cultural emblems that relate to the communities where found. When discussing African architecture generally, we are indirectly referring to art and culture that should be considered as a part of a whole. This paper mainly focuses on the kings' and chiefs' palaces where most of these artistic and cultural values are clearly spelt. These traditional structures are best referred to as galleries of creativity, which are gradually turning into ruins. The palaces are the custodians of artifacts, which could as well be tourist centers and can also be used to establish and interpret cultural sequence and history of the people.
\end{abstract}

Keywords: traditional architecture, African, cultural values, artistic element tourism, art, Yoruba people, artifacts.

\section{Introduction}

A sense of life is the source of art says Rand in her book titled "The Romantic Manifesto". She further adds that the emotion involved in art is not an emotion in ordinary meaning of the term; it is experienced more as a "Sense" or a "feel" 
with two characteristics pertaining to emotions [1]. As [2] also points out that a work of art is essentially individualistic in origin, and that from artist to artist there are differences in personality and temperament. All these two submissions go along with the concept of artistic creation among the black people of Africa. Writing about art and culture would be a floating exercise if not traced to the prehistoric man who created art images and structures to beautify his environment in the name of decoration and architecture. He found a shelter which he eventually made into his dwelling place. As [3] rightly suggests that it could be termed as the true rudimentary emergence of the artistic elements in man's architectural creation and decoration. As it has been variously suggested that these shelters could be termed as the true rudimentary emergence of the artistic elements in man's architectural creation and decoration, for this reason it is seen as a part of the culture that controls their existence here on earth. Aside of this, Yoruba art culture and architecture possess the realization of creative activity, and the native contexts of the objects in use are invested with religious feelings and not of aesthetic embodiment.

In most African societies, art is always tied to religion because it is part of their heritage. For this simple fact it is seen as a part of the culture that controls their existence here on earth. Art and culture are never considered globally but interpreted with the basic rudimentary elements that are combined to make a whole. Aside of this, function and meaning could be taken as crucial determining factors with which art and artistic objects are assessed in African art as a whole.

Yoruba art, culture and architecture possess the realization of creative activity, and native contexts of the objects in use are invested with religious feelings and not of aesthetic embodiment. Yoruba religious art, as it is in most black African societies, is interpreted in terms of its artistic elements such as the figures, symbols, patterns and colour symbolism. All these are taken as the legitimacy of the intellectual assessment canon.

In Yoruba land, art and culture occupy a salient position most especially those that are used as architectural embellishments in the kings' and important chiefs' palaces. The images and symbols as well as colours are usually attributed to the deities and answerable to religious beliefs and aspirations of the people [4]. The palaces are the store-house of culture with great concern about art and artifacts inform of paintings (mural) and carved wooden images and symbols. Sculptured objects, including figures and masks, patterns and semi-abstract representations, together with other unpleasant materials including blood, animal skins etc. are found as religious objects in palaces. These palaces contribute to greater appreciation of Yoruba art and culture.

It is valid to now add that Yoruba architecture is still responding to the dynamics of continuity and change in a way because the former artistic elements being used in the past are still in use today. They are still lending authority to the images of fear because of their religious obligations, they like wise inspire local artists. According to [5], emotionally, African sculptor is animated by fear of the mysterious elements about him: fear of the dead... fear of jungle beasts; fear of his fellow man; and fear of the forces of nature. All these fears are fundamental to the artistic creativity of the Yoruba traditional artists; the fear that directs their 
imagination to represent visually. Again and again... the arts of Africa cite the fear-laden emotions of the creators and users of these objects and reiterate the view that they are so much dominated by intense emotionality and fear [5]. Yoruba traditional artists (carvers and mural painters etc.) try to translate, discover, intensify and respond to the mystical aspects of Yoruba life. Some of the carved images seen in palaces and in other important traditional places are used to search from the unknown by trying to make the invisible seen in the mystical content within life.

As we reflect on the contributions of Yoruba people to the evolution and development of art, it is important to observe that before the evolution of sculptural art in America and Europe and elsewhere, stone carving and mud sculpture had existed in Yoruba land. I believe that Surrealism, Dadaism and some other modernist movements of the 1920s did not come to Africa as a new creative development, but as adaptations of already existing concepts which hitherto were familiar to indigenous African craftsmen. Although these works made by the Dadaists and surrealists and others were very impressive and eyecatching, they were not challenging and intriguing to the traditional and modern African artists as a whole. The reason is not farfetched, this is because African masking tradition (as those used in mural paintings and wood carvings in palaces) had given the African artists the opportunity to develop to high aesthetic level. The various carved images of which the Akwanshi, (among the people of Cross river state of Nigeria); Ere-Ibeji, (among the Yoruba); Akwaba (the Ashantis of Ghana) etc. stand out distinctly, as good examples of original art produced by anonymous African artists from black African countries. Conceptually, these art forms provided a channel of exploration into the social, religious and political feelings of the various societies in black Africa.

\section{Study area}

Yoruba arts, culture and architecture had from time past responded to the dynamics of continuity and change within the framework of Yoruba artistic elements, thus making the distinctive Yoruba features prominent. These artistic renderings could be seen in ile-ife, Ogbomoso, Ikere, Ila-Orogun and in most Yoruba towns and villages in south- western Nigeria where this research was carried out. The study embraces the Yoruba speaking areas of the republic of Dahomey, now Benin republic, located on the western part of the Yoruba land. These places have the same tradition and culture, which guide their architecture.

\section{Methodology}

In-depth interviews were conducted whereby knowledgeable people such as chiefs and court attendants were made use of. Existing information was also collected from books, journals to substantiate the oral information collected from these people. After ascertaining the data collected to be genuine, the facts were then synthesized and interpreted. The interviews were a hybrid of one-on-one interview approach in which the respondents were approached in their different 
place of work and at home. The point of view, feelings and perspective of the respondents were deeply explored. The questions asked captured the totality of the investigation and the answers led to some valuable questions concerning the deteriorating nature of the artistic elements in use on the architectural structures in the areas of study.

\section{Research finding}

The study identifies the Salient position art and culture occupies in the assessment of Yoruba architecture. Many writers who have variously written on Yoruba architecture did not venture to situate the importance of artistic elements in relation to architecture of the Yoruba palaces and pointing this to its relevance regarding tourism. The study equally discovers that works on form and meaning in Africa art particularly concentrate on the interpretation thereby giving no prominence to architecture and its elements in Yoruba land. Those interviewed did not understand that the content and form are essential to the proper understanding of the function of art as it relates to architecture.

The study then concludes that the cultural values inherent in the architecture of Yoruba palaces are fast fading away giving way to contemporary nature, thus reducing the concept of tourism regarding the use of Yoruba traditional Art and culture

\section{Yoruba society, its art and artists}

The king, Oba, is referred to as ekeji-orisa, next to the gods in importance among the Yoruba. They are placed on a high pedestal. Their palaces are usually referred to as the galleries of creativity and the custodian of artifacts which could serve as tourist centres.

Yoruba land is endowed with numerous art and artifacts which stand as cultural phenomenon that had its origin from various artistic orientations or traditions.

The local artists and craftsmen have used their own techniques to experiment in various directions in an effort to articulate their feelings and experiences into eventful works of art seen in palaces of the kings (oba) or important chiefs, (ijoye), in their various villages, towns and cities. These works are guided by their culture, in terms of structure, design and overall aesthetic appeal.

In the palaces of the Alaafin of Oyo, Ooni of Ife, Soun of Ogbomoso, the Ogoga of Ikere and other notable kings in Yoruba land, the main stylistic influences discovered are representational and modified abstract - representation mode of expression. The artists try to establish the originality in sculptural exploration and mural paintings. The carved doors and verandah posts contribute to greater appreciation of art in palaces of the notable kings and chiefs. The carving style has been the admixture of simple bas-relief, and deeply cut designs, which characterized late Oyo Yoruba carving style [6]. Apart from verandah posts and carved doors, art works found in palaces are numerous of such are, dance wand in wood found in Ila-Orangun, Ikere-Ekiti, Ogbomoso, Isehin, Ile- 
Ife, Oyo town, among the Atakpami of The Republic of Benin who are of Yoruba extraction, as well as in Egbado area of Yorubaland; the assemblages of pottery works, mud sculptures, statutes, carved seated figures, and art works in different forms, are kept in the palaces to serve as objects of tourism. Sometimes they are displayed in the museums attached to the palaces the best place to attract local and foreign tourists. This display would make known the uniquely creative, artistic and philosophical aspiration, socio-religious motivation and scope of Yoruba artists toward the development of tourism in Yoruba land. The exhibited works of art would equally help to provide the conceptual, philosophical and stylistic development of art in Yoruba area.

People from far and near are always eager to see the creative imagination of the local artists, and to evaluate how much they can put their latent socioreligious language into two or three dimensional forms to create authentic Yoruba visual art.

The art of the Yoruba of South-west Nigeria has a wide spectrum of usage. It is not limited to certain basic assumptions rather it is used within a well-defined cultural setting in which both the creator (the artist) and the beneficiaries (local and foreign tourists) share basic assumption about the nature of the work of art. Art work could be used freely to meet other socio-religious obligations such as festivals and other religious events.

During the annual Olojo and Edi and other festivals in Ile-Ife, as in other Yoruba towns, some of these arts and artifacts are assembled, worshiped and pacified with rites to make the religious ones efficacious. Annual celebrations call for people from all walks of life to participate. People enjoy the togetherness of the society as it is the time of reunion and for the propagation of tourism. There are series of festivals, some of these may involve the use of artifacts, such as masks, statutes carved and mud sculptural pieces. Dancing, feasting, sacrificing and blessing people also take place during these celebrations. People jubilate and use this occasion to solicit favours from the creator through the gods they worship. [6] asserts that there is a general feeling that the visible and the invisible worlds coexist for the benefit of man who is at the center. Most, if not all these annual celebrations attract people both foreign and local, thus the concept of tourism is created. These festivals are not entirely complete without the use of art objects, as [6] adds that often African Art expresses religious ideas we find on wood, stools, calabashes, stones, pots and handcrafts. All these are artistic elements with which art is created visually.

The most exciting thing about these local artists and craftsmen is that they work with culture guided principles and translate these into aesthetic statements about Yoruba culture in traditional / contemporary society. Their works of art could be said to have constituted a metaphor of achievement, reminding viewers of one of the few means by which the traditional artists can achieve economic success through tourism. The main gain of the artists comes from the sales of their works, which also depends on credibility. To gain credibility, artists need to excel in the society. Although these local artists have similar background, their main distinction lies in the usage of materials (wood, mud, metal etc.) artistic elements symbols, patterns, images, colours etc); representational styles, skill 
and in the use of formal and informal balance or otherwise in their composition, form and meaning. What should be made clear when assessing Yoruba art is the philosophy based on their indigenous culture, which has elevated their creative tendencies to a level of communal fame and achievement in the contemporary Nigerian society.

\section{Yoruba art and architecture}

The Yoruba palace architecture is built to assume a more permanent structure with thicker walls, more elaborate designs and larger spaces. The palaces are more defined by spatial variation of its sections such as verandah, courtyards etc. Yoruba palaces are relatively dedicated to the gods, Orisa, and could be termed the dwelling places of the gods. The task of ornamentation and decoration of Yoruba palaces lies on the communities and the priests in charge of the gods which the kings represent on earth. African people generally have their own respective religious places which are not for common use, they are considered sacred or holy. The kings and notable chiefs in the society normally reserve certain areas in the palaces where they express their religious feelings. These places are specially decorated with religious emblems to go with the tradition of the land. The architecture of the Yoruba is traditionally embedded in the use of art as the main source of aesthetic embellishment. Art is wholly linked to architecture both in structure and interpretation. For this reason the Yoruba have always considered artistic elements in the formative attitude of their palaces meant for the kings and notable chiefs in the society. The form encompasses the actual structure while the elements denote the various designs, patterns, motifs, symbols and colours in use, as decorative elements.

Yoruba architecture has always responded to the dynamic of continuity within the cultural boundary of Yoruba artistic elements. The artistry of Yoruba palaces is one that needs to be a better documented aspect of their cultural life. Their best known medium is wood which Yoruba artists carved both for internal use and for sale to tourists. Within the palace, we have handsomely carved verandah posts, doors and whole house fronts, elegant calabash utensils designed to contribute to their erotic appeal through both visual and tactile means. The ritual objects, such as masks, statutes, carved images and mud sculptures are decorated and used to serve as items for architectural consideration. They are also considered as part of social life of the people, though some of the items found in shrines enclosed in some palaces are towards the religious concern of the Yoruba. The artistic rendering of the various structures that combine to form the entire palace has relationship with the tradition of the people which they guide jealously.

It is sad to note that the former usage of culture-guided artistic elements in Yoruba architecture is no longer apparent in most palaces in Yoruba land, as it was in the past decades. Those that still survive the negative tendencies, such as erosion, crave for modernization, neglect, lack of cultural values on the part of the people etc. have been turned into tourist centres because they contain useful artifacts that could be used to interpret cultural sequence and history of the Yoruba. This is a good omen for tourism. 
In most Yoruba palaces, the old structures are usually enclosed in the new. Thus the traditional form is seen side by side with the contemporary type. The traditional structure could be referred to as the custodian of artifacts and religious objects, which could help support tourism. Thus a museum is being created within the palace. Both the immovable art works, such as the verandah posts and other decorated structures which are movable receive communal or societal attention inform of exhibitions. They all portray the same cultural values and interpretations.

Adaptation is now in vogue and this attitude could reduce tourist attraction. There should be a re-awakening of cultural heritage syndrome to enable us see into the past of the Yoruba people of south-west Nigeria. The culture-bound aesthetics that were cherished by all in the past that once stood as symbols of prestige among the Yoruba are gradually going into ruins. The forms and other artistic elements that used to favour tourism are now giving way to westernized culture.

Carvings that were once used on ritual posts, kings' thrones, door posts, posts and lintels that used to hold the roofs are now giving way to westernization, thus the concept of tourism is fast fading out, and with time, nothing will stand as a pointer to tradition that once cherished its culture in terms of Art and architecture. Yoruba architecture could be classified into two, secular and religious. Secular embraces the type that has mundane or common motifs, patterns and colour schemes, while the religious type has the emblems of religious symbols, motifs, images and colours. The artistic elements of the religious type relate to the gods and not for decorative purpose alone. For the tourists to enjoy the form of Yoruba religious architecture, interpretation of the motifs and colours is vital to documentation and tourists' interest.

[7] as well as [8] wrote on traditional architecture in Africa but little was said about the Yoruba architecture, or palace architecture that embraces the use of religious themes. The religious themes in carved images, patterns, and symbols are the attempts to articulate spiritual, emotional and aesthetic impulses. The themes are always the combination of opposites, time and eternity, personal and the cosmic, force and tenderness, male and female. These motifs used on walls in palaces or carved images in wood that serve as decoration on verandah posts, doors, window panes and other structural formations in the palaces are very essential for the portrayal of the spirits, gods and the ancestors of the Yoruba people. Generally, traditional Yoruba art expresses religious ideas, and they are expressed in the form of masks, and carvings on wood, metal work and sometimes in stone and mud as in mud sculptures. All these are the variously used in Yoruba architectural designs and formations. Local artists normally consult the kings and chiefs before embarking on new creations in the palaces. This is vital because kings' intentions and artistic preference must be taken into consideration simply because consultation with the gods and the ancestors might be necessary most especially if the design is to respond to the religious callings.

It is equally important to note that the existence of these religious arts help to elevate the status of palace architecture, thus creating avenue for tourist attraction. As earlier stressed the forms and other artistic elements that used to be 
the cynosure of all eyes are gradually fading out giving way to modern tendencies, thus the reduction of that cultural flair that has been the bane of creativity in art and architecture of the Yoruba.

\section{Conclusion}

Art, culture and the architecture of the Yoruba are interrelated, closing ranks in all artistic endeavours. Art and culture are very vital in justifying and in the assessment of what Yoruba architecture stands to represent visually. It is apparent to add that a departure from art and culture will render the traditional architecture of the Yoruba meaningless and uninteresting. Equally, the religious phenomenon which is usually considered primary in African thought is always given a pride of place in African art. For, according to [6], Nature is not conceived as of impersonal but is "filled with religious significance. Man gives life even where natural objects and phenomena have no biological life"and since this spirit power is manifested in all things, it could then be deduced that the carved religious items used as symbols of architectural embellishments are equally living since they can perform certain vital functions in the realm of existence. It would be discovered that the most outspoken and eloquent voice of the Yoruba art and culture is incontestable as they are important part of a whole architectural structures. The traditional art and architecture of the Yoruba still retain some interesting features that can introduce one into the past, and the role and meaning of some artistic elements together with the intellectual process and imagination of the artists could be determined. When all the homogenized communal ideologies found in Yoruba art, culture and architecture are fully realized, and then the concept of tourism would be seen to be possible in Yoruba identity and creative imagination.

\section{References}

[1] Rand, A.: The Romantic Manifesto New York. 1996.

[2] Read, H. A Personal Point of View: Summary of Dwellings." In the Artist in Tubil Society ed. M.W. London: Routledge and Kegan Paul. 1961

[3] Basil, D. The Last Cities of Africa. Garden City, New York 1965.

[4] Personal Interview with Pa Yusufu Gbadamosi of Ode-Olowo in Oshogbo $10^{\text {th }}$ April 2010.

[5] Myers, B.S., Art and Civilization. New York and Toronto; McGraw-Hill. 1967

[6] Mbiti, J.S., Introduction to African Religion: Heinemann Educational Book Ltd. London: WIX \& AH. 1979

[7] Chanda, J., African Art and Architecture. Redmond, WA Microsoft Cooperation. 2005

[8] Bourdeir, J, and Minh, T., Drawn from African Dwellings. American Association University Press 1996. 